\title{
OBSERVÂNCIA DE PRECEDENTES E GESTÃO DE DEMANDAS REPETITIVAS POR MEIO DO APRENDIZADO DE MÁQUINA
}

\author{
COMPLIANCE TO LEGAL PRECEDENTS AND REPETITIVE \\ LEGAL CASES MANAGEMENT WITH MACHINE LEARNING
}

\section{CUMPLIMIENTO DE PRECEDENTES JUDICIALES Y GESTIÓN DE DEMANDAS REPETITIVAS CON APRENDIZAJE AUTOMÁTICO}

Isabela Cristina Sabo*

Aires José Rover **

\begin{abstract}
1 Introdução. 2 Referencial teórico. 2.1 Evolução e abrangência do conceito de jurisdição civil. 2.2 O Código de Processo Civil de 2015 e o modelo brasileiro de jurisdição. 2.3 E-Judiciário E E-Jurisdição: notas sobre ia e a técnica de ML. 3 Apresentação e fundamentação da proposta. 3.1 Metodologia de pesquisa. 3.2 Estudo de caso 1 e discussão dos resultados. 3.3 Estudo de caso 2 e discussão dos resultados. 3.4 Possíveis aplicações de ML ao sistema de precedentes. 4 Conclusão. Referências. Apêndice A. Apêndice B.
\end{abstract}

\section{RESUMO}

O Poder Judiciário se apresenta como um dos focos de debate sobre a implementação de tecnologias relacionadas à Inteligência Artificial (IA), de onde advém a técnica de aprendizado de máquina (ML - machine learning). Nesse contexto, apresenta-se o problema de pesquisa: é possível que o aprendizado de máquina contribua para o funcionamento do sistema de precedentes? Partindo-se de uma hipótese inicial positiva e empregando-se o método indutivo, o artigo expõe um estudo de dois casos, com o levantamento de dados referentes a dois institutos processuais: um relacionado à não observância dos precedentes, a Reclamação; e outro pertinente às técnicas para julgamento de casos repetitivos, o Incidente de Resolução de Demandas Repetitivas (IRDR). A fim de contextualizar o tema e os objetivos do estudo, a pesquisa apresenta a evolução do conceito de jurisdição, reportando-se às alterações trazidas

\footnotetext{
* Doutoranda em Direito pela Universidade Federal de Santa Catarina (UFSC). Bolsista do CNPq. Mestra em Direito Negocial pela Universidade Estadual de Londrina (UEL). Graduada em Direito pela Universidade Estadual de Maringá (UEM). Universidade Federal de Santa Catarina (UFSC). Florianópolis, SC, BR. E-mail: <isabelasabo@gmail.com>. http://orcid.org/0000-0003-4246-3997

** Doutor, Mestre e Graduado em Direito pela Universidade Federal de Santa Catarina (UFSC). Professor Associado da Universidade Federal de Santa Catarina (UFSC). Universidade Federal de Santa Catarina (UFSC). Florianópolis, SC, BR. E-mail: <aires.rover@gmail.com>. http://orcid.org/0000-0003-1070-5357
} 
pelo Código de Processo Civil (CPC) de 2015; e, ainda, as noções de E-Judiciário e E-Jurisdição combinadas com as funcionalidades da IA, bem como trabalhos relacionados utilizando a técnica de ML. Com isso, a proposta de possíveis aplicações envolvendo a técnica de ML se fundamenta na identificação desses dois institutos relacionados ao funcionamento do sistema de precedentes, que podem ser aperfeiçoados com a implementação da tecnologia, no intuito de atingir um modelo de jurisdição inteligente.

Palavras-chave: E-Judiciário. Jurisdição civil. Aprendizado de máquina. Processo eletrônico. Precedentes.

\begin{abstract}
Brazilian Judiciary is presented as one of the focus of discussion on the implementation of technologies related to Artificial Intelligence (AI), from which comes the machine learning (ML). In this context, the research problem is presented: is it possible that machine learning contributes to the functioning of the legal precedents system? Starting from an initial positive hypothesis, and using the inductive method, the article presents a study of two cases, with data collection about two procedural institutes: one about the non-compliance to legal precedents, the "Reclamação" [sic]; and another about the techniques for management of repetitive cases, the "Incidente de Resolução de Demandas Repetitivas (IRDR)" [sic]. In order to contextualize the theme and objectives of the study, the research presents the evolution of the concept of jurisdiction, referring to the changes brought by the Brazilian Code of Civil Procedure (2015), and still the notions of E-Judiciary and e-jurisdiction combined with the functionalities of AI, as well as related work using ML. Thus, the proposed ML applications are based on the identification of these two procedural institutes, related to the operation of the legal precedence system, which can be improved with the implementation of the technology to achieve a model of intelligent civil jurisdiction.
\end{abstract}

Keywords: E-Judiciary. Civil jurisdiction. Machine learning. Electronic process. Legal precedents system.

\title{
RESUMEN
}

La justicia brasileña es foco de debate sobre la implementación de tecnologías relacionadas con la Inteligencia Artificial (IA), donde proviene la técnica de aprendizaje automático (ML machine learning). En este contexto, se presenta el problema de investigación: ¿es posible que el aprendizaje automático contribuya al funcionamiento del sistema brasileño de precedentes judiciales? Partiendo de una hipótesis inicial positiva, y utilizando el método inductivo, el artículo expone un estudio de dos casos, con recolección de datos pertinente a dos institutos procesales brasileños: uno relacionado con el incumplimiento de precedentes judiciales, la "Reclamação" [sic]; y otro relacionado con la gestión de demandas repetitivas, el "Incidente de Resolução de Demandas Repetitivas (IRDR)” [sic]. Para contextualizar el tema y los objeti- 
vos del estudio, la investigación presenta la evolución del concepto de jurisdicción, haciendo referencia a los cambios introducidos por el Código Procesal Civil brasileño de 2015. Se presenta, además, las nociones de e-justicia y e-jurisdicción combinada con las funciones de IA, así como los trabajos relacionados utilizando la técnica de aprendizaje automático. La propuesta de posibles aplicaciones que involucren el aprendizaje automático se basa en estos institutos procesales relacionados con el cumplimiento del sistema de precedentes judiciales, que se puede mejorar con la implementación de la tecnología para alcanzar un modelo de jurisdicción inteligente.

Palabras clave: E-justicia. Jurisdicción civil. Aprendizaje automático. Proceso judicial electrónico. Precedentes judiciales.

\section{INTRODUÇÃO}

O Poder Judiciário é, atualmente, um dos principais focos de debate sobre a implementação de tecnologias inerentes à Inteligência Artificial (IA), de onde advém a técnica de aprendizado de máquina (ML - machine learning). Essas aplicações, de modo geral, visam à melhora da prestação jurisdicional em termos de celeridade e eficiência do processo.

A partir dessa realidade, apresenta-se o seguinte problema de pesquisa: é possível que a técnica de ML contribua para o funcionamento do sistema de precedentes do Código de Processo Civil (CPC) de 2015? A hipótese inicial é positiva, o que leva à reflexão de que é possível, com isso, tornar a jurisdição inteligente.

Sendo assim, traçam-se os seguintes objetivos:

1. No campo teórico, elaborar uma revisão bibliográfica e documental apresentando a evolução conceitual do que se compreende por jurisdição civil, em sua esfera interna e externa, atribuindo enfoque ao modelo brasileiro, ocasião em que se discutem as alterações e os objetivos trazidos pelo CPC de 2015; a revisão também conterá uma breve exposição sobre IA e ML no contexto internacional e nacional, apresentando as noções de E-Judiciário e de E-Jurisdição, assim como trabalhos relacionados utilizando ML (seções 2.1, 2.2 e 2.3).

2. No campo prático, levantar dados processuais para demonstrar que alguns institutos presentes no CPC de 2015 não estão sendo desempenhados conforme almejado pelo legislador, refletindo no funcionamento do sistema de precedentes (seções 3.1, 3.2 e 3.3), e apontar, a partir desse diagnóstico, as possíveis aplicações que contribuirão para o melhor funcionamento desse sistema (seção 3.4). A metodologia utilizada será explanada na seção 3.1.

A justificativa desta pesquisa reside na atualidade do tema, bem como na ausência de estudos jurídicos de caráter empírico com vistas a embasar a técnica de ML no Poder Judiciário brasileiro. Assim, o artigo poderá auxiliar os operadores do Direito e de outras áreas do conhecimento, no sentido de que os benefícios da tecnologia sejam devidamente explorados e que os resultados sejam não só positivos, mas também visíveis na entrega da prestação jurisdicional. 
Não se pretende a validação da proposta, dado que, para tanto, seria necessário perquirir, a fundo, as tecnologias de IA e suas peculiaridades - em especial o(s) algoritmo(s) específicos - aplicáveis em cada caso examinado, fazendo-se imprescindível propor experimentos com especialistas, ir a campo para testá-los na prática forense, obter resultados específicos e discuti-los.

\section{REFERENCIAL TEÓRICO}

\subsection{EVOLUÇÃO E ABRANGÊNCIA DO CONCEITO DE JURISDIÇÃO CIVIL}

São variadas as concepções de jurisdição ao longo da história da disciplina de Teoria Geral do Processo e de Direito Processual Civil. A prestação jurisdicional é vista de modos distintos e conforme a necessidade de cada contexto histórico. Por isso, a academia jurídica preocupa-se em classificar modelos de jurisdição no sentido de compreender a realidade social da época.

De acordo com Chiovenda (2000, p. 58-60), a jurisdição está relacionada com a função essencial e exclusiva do Estado e consiste no poder de atuar conforme a vontade da lei no caso concreto. Essa função pública compete ao juiz, enquanto autoridade judiciária, em conjunto com os demais órgãos jurisdicionais, e é desenvolvida no processo. Na mesma linha, para Carnelutti (2000, p. 147-148), a jurisdição é destinada à produção do direito, que é dito pelo Estado-juiz por meio do processo, podendo servir-se dos elementos úteis fornecidos pelas partes no momento de instruir o caso e declarar o comando (a decisão).

De modo distinto, a visão de Calamandrei (1957, p. 45-47) a respeito da jurisdição se concretiza em uma espécie de "jogo racional” entre as partes. Nela, a função do Estado-juiz é exercida de acordo com a parte que melhor conseguiu, com os meios técnicos apropriados, provar que possui a razão, de modo que a sentença não é um produto automático da aplicação das leis aos fatos, e sim o resultado das forças em jogo. Em sentido próximo, o estudo de Pontes de Miranda (1998, p. 180-185) demonstra que a sentença é emitida como uma prestação do Estado, porém em virtude da obrigação assumida na relação jurídica processual quando as partes vierem a juízo, isto é, exercerem a pretensão à tutela jurídica.

Interpretando-se as noções apresentadas, é possível distinguir dois modelos gerais de jurisdição: o modelo publicista e o modelo privativa. De um lado, infere-se que o modelo publicista, de viés constitucional, concebe o processo como um serviço público a ser prestado pelo Estado-juiz, de modo que o objetivo principal da jurisdição reside em dizer o direito, justificando-o por meio da decisão (CHIOVENDA, 2000; CARNELUTTI, 2000). De outro, compreende-se que, de acordo com modelo privatista, de tendência cooperativa, o processo é idealizado como uma espécie de "quase contrato", ao passo que a jurisdição visa a dizer o direito, explicando-o para as partes (CALAMANDREI, 1957; PONTES DE MIRANDA, 1998).

Analisando a jurisdição no âmbito global, Damaska (1986, p. 16-28) labora em uma exposição comparativa entre diferentes modelos. $\mathrm{O}$ autor distingue, a princípio, o modelo hierárquico ("Hierarchical Ideal") e o modelo paritário ou coordenado ("Coordinate Ideal"). No modelo hierárquico, enraizado no civil law, a justiça ocorre de forma centralizadora, à medi- 
da que os poderes e os deveres dos juízes decorrem da lei, em uma relação de subordinação. Os critérios de decisão são baseados na legalidade, e os recursos são enviados ou julgados diretamente por instâncias superiores, o que faz com que os juízes e os Tribunais sejam mais especializados e burocráticos. Diferentemente, no modelo paritário, cujas bases são encontradas no common law, a justiça é descentralizada, e nem sempre a decisão é fundamentada primordialmente pela lei, de forma que a jurisdição é menos especializada.

De um lado, no modelo hierárquico, o processo é político (“policy-implementing process”), ou seja, o juiz o comanda de perto e interfere na produção de provas, tomando medidas de ofício que o aproximem do melhor julgamento de acordo com as políticas do Estado formalizadas em dispositivos legais. Por essa razão, há maior espaço para discussão da eficácia da decisão proferida em primeiro grau via inúmeras instâncias recursais. De outro, no modelo partidário, as partes são livres para selecionar o procedimento que melhor se adapta aos seus interesses ("conflict-solving process"), que é composto por mecanismos processuais concebidos para evitar que o litígio surja, ou, então, para resolvê-lo sem prejudicar a integridade do procedimento estabelecido. Nele defende-se a interferência mínima do Estado-juiz, o qual raramente se manifesta, limitando-se à supervisão (DAMASKA, 1986, p. 98-172).

Damaska (1986) conclui o seu estudo afirmando que não há mais, a nível global, um sistema processual puro, sendo presenciado em países que adotam o civil law traços de "conflict-solving process"; e, não diversamente, sendo verificados contornos de "policy-implementing process" em países que se baseiam no common law. Nesse sentido, também é a análise de Taruffo (2003), ao exemplificar, no common law, a possibilidade de o juiz desempenhar papel ativo no plano das iniciativas probatórias e as técnicas de se obter conciliação entre as partes, prescindindo-se a decisão judicial; e, no civil law, a tutela jurisdicional dos interesses difusos e a unificação de fases processuais.

À vista da investigação exposta, percebe-se uma tendência de superação da distinção entre os modelos apresentados, seja na concepção interna de publicista ou privatista, seja do ponto de vista externo do common law ou civil law. A rotulagem de um modelo de jurisdição acaba por ser inviável frente aos esforços de melhoria da prestação jurisdicional em cada país e aos limites de sua respectiva cultura. Nesse ponto, o Brasil, sobretudo com o CPC de 2015, tem incorporado características de todos os modelos expostos, o que será examinado adiante.

\subsection{O CÓDIGO DE PROCESSO CIVIL DE 2015 E O MODELO BRASILEIRO DE JU- RISDIÇÃO}

No Brasil, historicamente, preponderaram-se as características do civil law e do modelo publicista, em que pesem as reformas constitucionais e infraconstitucionais, bem como as revisões que o CPC de 1973 sofreu ao longo dos seus anos em vigência. Entretanto, o CPC de 2015 ratificou importantes alterações paradigmáticas na relação jurídica processual, cujos traços remontam ao common law e ao modelo privatista.

De modo geral, o CPC de 2015 alinha o processo à principiologia constitucional e, ao 
mesmo tempo, estabelece a necessidade de colaboração entre as partes que a ele se sujeitam. Daí percebe-se o intercruzamento dos modelos publicista e privatista ${ }^{1}$, que traça como principais objetivos a publicidade, a eficiência e a celeridade - já conhecidos pelo CPC de 1973 -, como também a estabilidade, a integridade e a coerência das decisões, além da segurança jurídica do sistema processual².

De modo específico, no aspecto decisional, menciona-se a imposição de um sistema de precedentes, vinculando os juízes de primeira instância às decisões dos Tribunais Superiores ${ }^{3}$, além de disciplinar técnicas processuais voltadas às causas repetitivas, no sentido de obter decisões coerentes e não conflitantes entre si, como o incidente de resolução de demandas repetitivas e o julgamento de recursos especial e extraordinários repetitivos ${ }^{4}$. Esse modelo, porém, não é inovador, pois indica uma prática exercida pela comunidade jurídica antes da vigência da lei processual atual, uma vez que subsunção entre fato e norma já não se operava com base eminentemente na lei, e sim à vista das decisões dos Tribunais em geral.

Afirma-se, então, que a segurança jurídica e a estabilidade das decisões são objetivos buscados por qualquer sistema jurídico em um Estado Democrático de Direito, opere ele no modelo common law ou civil law, ainda que estes percorram caminhos diferentes para tanto. Esses princípios estão relacionados entre si, uma vez que é fundamental que uma sociedade detenha a possibilidade de antever a repercussão (especialmente jurídica) de seus atos, a fim de direcioná-los em um determinado sentido. No Brasil, atualmente caracterizado por um modelo híbrido, esses princípios têm se apresentado em uma realidade complexa, dada a possibilidade de juízes e Tribunais não observarem os precedentes decorrentes dos Tribunais Superiores, pois, tendo o julgador liberdade para decidir de acordo com suas próprias convicções, ainda não se superou o cenário no qual existem condutas e, consequentemente, decisões diferentes (e incompatíveis entre si) diante dos jurisdicionados (WAMBIER, 2009, p. 121-124 e 131).

Isso porque, antes da imposição pelo CPC de 2015, o precedente possuía força persuasiva, servindo apenas como diretriz para julgar. No direito anglo-saxão, por sua vez, o precedente possui força vinculativa, o que significa que aquilo que foi estabelecido no caso antecedente deverá ser aplicado e define o julgamento do caso subsequente. Nesse modelo, há a adoção do stare decisis ${ }^{5}$ em sua versão mais rígida, de modo que há extrema aversão à ideia de que precedentes possam ser modificados. No Brasil, embora o juiz de primeiro grau, por si só, não possua autoridade para derrogar um precedente dos Tribunais Superiores, era possível,

1 Ver art. $1^{\circ} \mathrm{e}$ art. $6^{\circ}$ (BRASIL, 2015).

2 Ver arts. 926, § $1^{\circ}$, e 927 , §§ $3^{\circ}$ e $4^{\circ}$ (BRASIL, 2015).

3 Ver art. 927, caput e incisos (BRASIL, 2015).

4 Ver art. 928, art. 976 e art. 1.036 (BRASIL, 2015).

5 Nas palavras de Cole (1998, p. 11), stare decisis é a "[...] política que exige que as Cortes subordinadas à Corte de última instância que estabelece o precedente sigam aquele precedente [...]" e não alterem o entendimento de uma questão decidida anteriormente pela Corte de última instância. Segundo Re (1994, p. 47), a aplicação de uma decisão judicial na solução de casos semelhantes no futuro implica na possibilidade de que futuras causas parecidas ou idênticas venham a ser decididas da mesma maneira e encontrem uma solução que forme um entendimento uniforme. $\mathrm{O}$ caso anteriormente decidido, portanto, funcionaria como um ponto de partida para os casos futuros. 
até o CPC de 2015, ele proferir uma decisão que se distanciasse da corrente jurisprudencial majoritária, sem comprometer a sua higidez formal ou validade técnico-jurídica (OLIVEIRA, 2013, p. 15-16). Esse tipo de conduta compromete o sistema de precedentes, que só funcionará à medida que sejam ratificados pelos demais Tribunais e juízes de $1^{\circ}$ grau.

A vinculação estabelecida pelo CPC de 2015 pretende alterar esse cenário por meio da gestão e do julgamento de casos repetitivos e da formação concentrada de precedentes obrigatórios, como exposto. Ambos pretendem estabelecer categorias de decisões judiciais que, uma vez proferidas pelos Tribunais Superiores, possuirão caráter vinculante, isto é, deverão ser inteiramente observadas, sob pena de cassação do comando judicial que as desrespeitarem a partir da propositura de simples reclamação pela parte interessada ${ }^{6}$.

Vale lembrar que um dos motivos que leva a essas alterações é a explosão acarretada pelo desmesurado aumento dos processos, que vem rotinizando a jurisdição brasileira e levando os Tribunais, principalmente o STJ e STF, à filtragem dos recursos e o manuseio de questões repetitivas, relevantes, peculiares à repercussão. Afirma-se ser humanamente impossível dar vazão ao ambiente processual presente e aos conflitos que adentram as instâncias Superiores, além do custo e da impossibilidade do julgamento colegiado, em virtude de priorização de temas, matérias e suas relevâncias (ABRÃO, 2017, p. 114).

O que se pretende demonstrar, a seguir, é que todos esses objetivos lançados pelo CPC de 2015 com vistas à melhoria da prestação jurisdicional só poderão ser efetivamente concretizados a partir de um aparato tecnológico inteligente, fornecido pelo próprio Poder Judiciário, que administre o alto número de demandas e que auxilie o trabalho do julgador, assim como dos demais serventuários da Justiça, nas demandas semelhantes e de menor complexidade.

\subsection{E-JUDICIÁRIO E E-JURISDIÇÃO: NOTAS SOBRE IA E A TÉCNICA DE ML}

E-Judiciário, ou Poder Judiciário eletrônico, consiste no poder do Estado com a função precípua de resolver os conflitos de interesses e proporcionar a paz social, com a diferença do traço tecnológico no sentido de modernizar a instituição e os meios pelos quais se presta a tutela jurisdicional. A partir dessa noção geral, é possível afirmar que o E-Judiciário abarca, por sua vez, a ideia de e-jurisdição, dado que no cenário contemporâneo, a tutela jurisdicional passa a ser prestada por meio do processo eletrônico (MEZZAROBA et al., 2016, p. 30).

A concepção de um modelo de jurisdição inteligente, por sua vez, é formada a partir do instante em que a tutela jurisdicional é prestada com o auxílio dos sistemas de IA. Inteligência Artificial (IA) está relacionada ao estudo de cálculos que tornam possível perceber, raciocinar e agir. Definir IA, segundo Winston (1984, p. 1), demanda um longo estudo e, mesmo com isso, não há a certeza de que determinada definição é acertada. Todavia, de forma geral, em termos operacionais, é possível afirmar que seu primeiro objetivo é tornar máquinas mais inteligentes, ao passo que seu segundo objetivo é compreender o que é inteligência, atribuindo maior utilidade às máquinas.

$6 \quad$ Ver art. 988 e seguintes (BRASIL, 2015). 
De forma específica, os objetivos da IA podem ser visualizados sob duas perspectivas: de engenharia e de ciência. $\mathrm{O}$ objetivo de engenharia é solucionar problemas do mundo real usando IA com um instrumental de ideias sobre representação e uso de conhecimento e montagem de sistemas, ao passo que o objetivo científico é determinar quais ideias sobre representação e uso de conhecimento e montagem de sistemas explicam diferentes tipos de inteligência (WINSTON, 1992, p. 5-6).

Um agente inteligente, assim entendido como uma entidade integrada que envolve um sistema de computador e seus usuários, dispõe de: a) autonomia, visto que o agente opera sem a intervenção direta do usuário ou de outros agentes; b) habilidade social, uma vez que o agente interage com outros agentes por meio de algum tipo de linguagem de comunicação; c) reatividade, dado que o agente percebe o ambiente ao seu redor e responde oportunamente às mudanças que acontecem; e d) proatividade, haja vista o agente não só agir em resposta ao ambiente, como também tomar iniciativa a partir de um objetivo. A IA busca, com o desenvolvimento computacional, uma inteligência de máquinas que seja similar à inteligência do homem (ROVER, 2001, p. 60-62).

Dentre as técnicas de IA para a construção e o desenvolvimento de um agente inteligente, a que mais interessa ao presente estudo consiste no aprendizado de máquina - "machine learning" (ML).

O aprendizado de máquina consiste em programar computadores para otimizar um critério de desempenho usando dados de exemplo ou de experiências anteriores. $\mathrm{O}$ aprendizado se faz necessário em casos nos quais não seja possível escrever diretamente um programa de computador para solucionar um determinado problema, porém, necessite de dados de exemplo ou de experiência. Um caso em que o aprendizado é necessário, por exemplo, é quando a perícia humana é inexistente ou quando os humanos sejam incapazes de explicar suas perícias (ALPAYDIN, 2009, p. 25).

É possível afirmar que o campo da aprendizagem tem sido o mais completo para se desenvolver sistemas de IA, além de abarcar os métodos dos demais campos, sendo atualmente de maior interesse para o estado da arte. O que se propõe, nessa área da IA, é construir máquinas com capacidade de aprendizagem e depois ensiná-las. A ideia por trás da aprendizagem é que as percepções devem ser usadas não apenas para agir, mas também para melhorar a habilidade do agente para agir no futuro. Ela ocorre à medida que o agente observa suas interações com o mundo e com seus próprios processos de tomada de decisão. A vantagem é que a aprendizagem permite ao agente operar em ambientes inicialmente desconhecidos e se tornar mais competente do que seu conhecimento inicial sozinho poderia permitir (RUSSEL; NORVIG, 2004, p. 51 e p. 629).

Algoritmos eficazes têm sido criados para certos tipos de tarefas de aprendizagem, dando-se abertura ao surgimento de aplicações comerciais significativas. Para problemas como reconhecimento de fala, algoritmos baseados em aprendizado de máquina superam todas as outras abordagens que foram tentadas até agora. No campo conhecido como mineração de dados, 
os algoritmos de aprendizado de máquina estão sendo usados rotineiramente para descobrir conhecimento valioso de grandes bancos de dados comerciais contendo registros de manutenção de equipamentos, pedidos de empréstimo, transações financeiras, registros médicos etc. Assim, é inevitável que o aprendizado de máquina desempenhe um papel cada vez mais central no âmbito das tecnologias de informação e comunicação (MITCHELL, 1997, p. 1-2).

A Figura 1 demonstra, resumidamente, as fases do processo de aprendizado de máquina:

Figura 1 - Processo de aprendizado

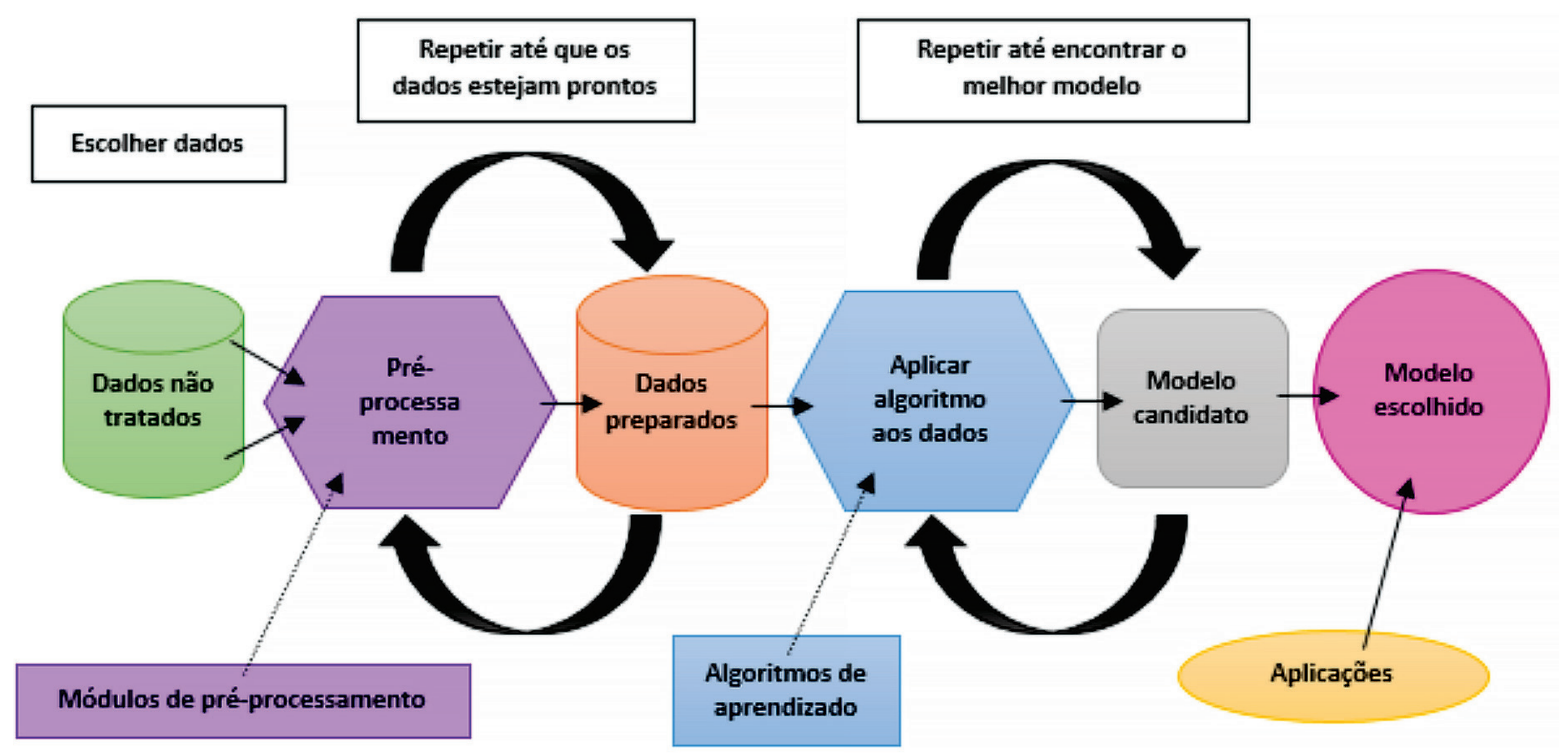

Fonte: adaptado pelos autores com base em Chappell (2015, p. 5).

Assim, é possível convergir os objetivos da IA e, a partir da técnica de ML, propor aplicações voltadas ao mundo jurídico. São diversos os campos sujeitos ao aperfeiçoamento por meio dessa técnica, e isso inclui desde a simples leitura de uma petição inicial em maior velocidade até a tomada de decisões.

Nessa linha, alguns trabalhos envolvendo a técnica de ML em diferentes modelos no ambiente jurídico decisional devem ser mencionados.

No contexto internacional, um experimento realizado na Corte Europeia de Direitos Humanos $(\mathrm{CEDH})$, com o intuito de prever decisões, executou uma classificação binária tendo como entrada os dados textuais extraídos dos casos a ela submetidos e como saída o julgamento real deles sobre a violação ou não a determinado artigo da Convenção Europeia dos Direitos Humanos. Um banco de dados foi formado a partir de decisões relacionadas a 3 (três) artigos da Convenção. Os resultados indicaram que a seção "fatos" de um caso é o fator preditivo mais importante, isto é, a tomada de decisão judicial é significativamente afetada pelo estímulo dos fatos narrados (ALETRAS et al., 2016).

Outro experimento ocorreu no âmbito do sistema italiano eJRM (Justice Relationship 
Management), que fornece apoio a cidadãos leigos, a estudantes e a mediadores para a obtenção de soluções jurídicas sobre determinado caso. Nesse experimento, o sistema é alimentado por decisões judiciais que são recuperadas no momento em que o caso em língua natural é apresentado. Sua arquitetura é composta por 4 (quatro) etapas: 1) Indexação: destina-se a armazenar as decisões judiciais em um banco de dados; 2) Mineração de núcleo: treina um modelo de classificação para prever o campo jurídico a que determinada descrição do caso apresentado pertence; 3) Processamento de consulta: extrai os termos relevantes da consulta que será usada pela mineração do núcleo para prever o campo jurídico do texto em disputa; 4) Ranking: recupera e classifica decisões judiciais relevantes (pertencentes ao campo jurídico previsto) a serem apresentadas aos disputantes e mediadores (EL JELALI; FERSINI; MESSINA, 2015).

Houve ainda um experimento sobre a portabilidade de modelos de aprendizado de máquina em diferentes tipos de documentos jurídicos no contexto alemão. Nesse caso, a portabilidade de domínio consiste na capacidade de um modelo ML para executar sua tarefa designada em um domínio diferente daquele em que foi originalmente treinado. Diferentes classificadores foram treinados sobre a legislação de locação do Código Civil Alemão (BGB) cujos modelos resultantes foram aplicados posteriormente em um conjunto de contratos de locação. O desempenho dos modelos variou no conjunto de contratos. Alguns modelos apresentaram um desempenho significativamente pior, enquanto certas configurações revelaram uma portabilidade (GLASER; SCEPANKOVA; MATTHES, 2018).

Finalmente, no contexto nacional, destaca-se o projeto VICTOR, atualmente em andamento, composto por uma equipe multidisciplinar de pesquisadores da Universidade de Brasília (UnB), que tem como objetivo aplicar técnicas de ML para resolver um problema de reconhecimento de padrões em textos de processos judiciais que chegam ao Supremo Tribunal Federal (STF). Especificamente, o problema a ser resolvido é a classificação (vinculação) de processos em temas de repercussão geral (RG) do STF. Isto é, trata-se de um problema de processamento de linguagem natural - "natural language processing” (NLP) -, o que especificamente requer o desenvolvimento de um sistema composto por algoritmos de aprendizagem de máquina que viabilize a automação de análises textuais desses processos judiciais (SILVA, 2018, p. 89).

O projeto é composto por 2 (duas) etapas: 1) Classificação de 5 (cinco) tipos de peças dentro de um processo (meta secundária): Acórdão, Recurso Extraordinário (RE), Agravo de Recurso Extraordinário (ARE), Despacho e Sentença; 2) Classificação de temas de repercussão geral (meta principal): após a classificação de peças, inicia-se a fase de classificação de temas contando com a automação da segmentação dos 5 (cinco) tipos de peças importantes para a identificação dos temas de RG. A meta principal é relacionar um processo inteiro a um ou mais temas de RG. Inicialmente, o VICTOR trabalhou com cerca de 14.000 processos, de um conjunto de cerca de 200 mil processos históricos, em que constaram somente processos públicos, sem nenhum conteúdo sigiloso (SILVA, 2018, p. 90-94).

Para além dos trabalhos existentes, é possível que outros campos do Poder Judiciário 
sejam aperfeiçoados com a aplicação de técnicas de ML. Para tanto, é preciso identificá-los, para, com isso, propor as possíveis aplicações.

\section{APRESENTAÇÃO E FUNDAMENTAÇÃO DA PROPOSTA}

\subsection{METODOLOGIA DE PESQUISA}

A metodologia do trabalho subdivide-se em: a) método de abordagem e b) procedimento e técnica.

O método de abordagem da pesquisa consiste no indutivo, por meio do qual, em uma lógica ascendente, é possível alcançar conclusões mais amplas em comparação ao conteúdo estabelecido pelas premissas nas quais o pesquisador se fundamenta. Essa generalização ocorre com base na identificação de fenômenos da realidade. Desse modo, a indução parte de um fenômeno da realidade em específico para atingir uma solução geral (MEZZAROBA; MONTEIRO, 2006, p. 63).

O procedimento empregado corresponde ao estudo de dois casos: b.1) as reclamações autuadas pelo Superior Tribunal de Justiça (STJ) no período de 18 de março de 2016 a 04 de julho de 2018, e que foram a julgamento nesse mesmo período; e b.2) os processos suspensos em razão de incidentes de resolução de demandas repetitivas (IRDR) do TJDFT, no período de 18 de março de 2016 a 04 de julho de 2018.

A técnica empregada consistiu na análise de dados coletados em processos disponíveis via consulta pública nos sítios eletrônicos do Superior Tribunal de Justiça (STJ) (http://www.stj. jus.br/portal/site/STJ) e do Tribunal de Justiça do Distrito Federal e dos Territórios (TJDFT) (http://www.tjdft.jus.br/). A especificidade de cada caso investigado será exposta adiante.

\subsection{ESTUDO DE CASO 1 E DISCUSSÃO DOS RESULTADOS}

O caso 1 se refere a uma amostra de 75 (setenta e cinco) reclamações autuadas no período de 18 de março de $2016^{7}$ a 04 de julho de $2018^{8}$ e que foram a julgamento nesse mesmo período, todas coletadas, como exposto, via consulta processual pública junto ao sítio eletrônico do STJ. A Tabela 1 dos anexos ilustra a coleta integral dos dados processuais obtidos, a qual está organizada por ordem de data de autuação.

Justifica-se a escolha do STJ para análise de reclamações pelo fato de que, nos termos do art. 105, III, da CF/88, o papel primordial do STJ na jurisdição brasileira é preservar a autoridade da lei federal no País e uniformizar o seu entendimento. Desse modo, ao julgar as reclamações recebidas, em que o propósito processual é a garantia da autoridade e da observância das decisões hierarquicamente superiores, o STJ cumpre, significativamente, a sua atribuição constitucional.

Ao final do estudo, foi possível aferir que da amostra total de 75 (setenta e cinco) re-

7 Início da vigência do CPC de 2015.

8 Data final da busca. 
clamações, 37 (trinta e sete) obtiveram o julgamento de procedência e 3 (três) obtiveram o julgamento de procedência parcial, ao passo que as 35 (trinta e cinco) reclamações restantes obtiveram o julgamento de improcedência, ou de não conhecimento/não provimento. $\mathrm{O}$ gráfico representado pela Figura 2 ilustra esses resultados:

Figura 2 - Resultados dos julgamentos das reclamações representados em porcentagem

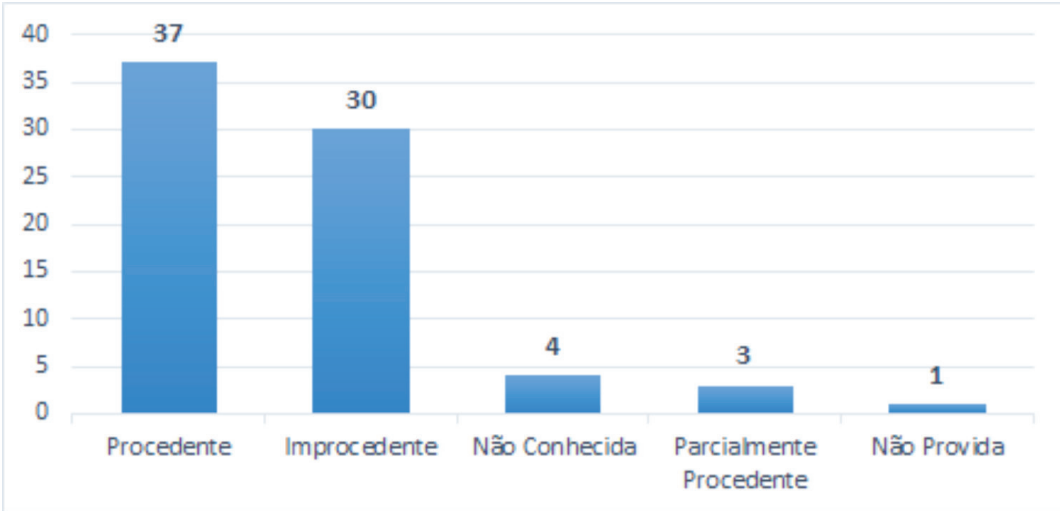

Fonte: desenvolvido pelos autores.

A reclamação se apresenta, hoje, como o meio específico destinado a assegurar a autoridade dos Tribunais, principalmente a dos Superiores, a fim de retificar possíveis incongruências advindas de decisões proferidas pelos demais julgadores que ultrapassem a relação de subordinação.

Isso porque, ainda com a observância obrigatória, é possível que casos concretos sejam decididos puramente com base em ementas, com a simples transcrição do resumo de um julgado, em uma espécie de acoplamento do caso anterior ao caso presente. Isso acaba gerando uma espécie de "cultura de ementas", que define os contornos e o conteúdo do Direito a partir da palavra final dada pelos Tribunais Superiores. A consequência disso é a criação artificial de um senso comum teórico na comunidade jurídica, que ultrapassa a interpretação e aniquila posições críticas. $O$ Direito passa a ser enxergado desvencilhado de sua facticidade, pois as decisões apenas se reproduzem, sendo desprovidas de raciocínio jurídico à medida que passam a ser redigidas com a pretensão de servirem como resposta automática a casos futuros (SCHMITZ, 2013, p. 2-3, p. 8-9).

Nessa perspectiva, depreende-se que as porcentagens relativas aos julgamentos de procedência e procedência parcial somam o total de 53,3\%. Trata-se de um número expressivo que permite algumas constatações, como o fato de que as decisões do STJ não estão sendo observadas pelos demais Tribunais e juízes desde a vigência do CPC de 2015, que, em seu art. 926, expressamente lhes impõe essa obrigação, e, ainda, o fato de que o STJ esteja, efetivamente, buscando com maior anseio assumir a posição de tribunal superior que preza pela uniformidade da jurisprudência. Tais constatações outrora contribuem com a compreensão de que o cenário de insegurança jurídica permanece no Poder Judiciário brasileiro. 


\subsection{ESTUDO DE CASO 2 E DISCUSSÃO DOS RESULTADOS}

O caso 2 trata-se da análise dos processos afetos por 3 (três) IRDRs pertencentes ao TJDFT 9 . O objetivo dos incidentes, em síntese, é a fixação de termo inicial dos juros de mora em ação de resolução imotivada de contrato de compra e venda de imóvel ajuizada pelo comprador quando inexiste mora anterior da incorporadora. Os incidentes foram propostos por empresas do ramo imobiliário atuantes em Brasília e região.

A análise se refere, então, a uma amostra de 40 (quarenta) processos suspensos no período de 25 de julho de $2016^{10}$ a 04 de julho de $2018^{11}$, todos coletadas, como exposto, via consulta processual pública junto ao sítio eletrônico do TJDFT. A Tabela 2 dos anexos ilustra a coleta integral dos dados processuais obtidos, a qual está organizada por ordem de data de suspensão. Os processos coletados possuem, ao menos, uma das empresas interessadas na qualidade de ré/requerida.

Justifica-se a escolha dos mencionados incidentes pelo fato de que o IRDR 1 foi objeto do primeiro pedido de suspensão, a nível incidental, de todos os processos em curso no território nacional, autuado pelo STJ em 02/12/2016 ${ }^{12}$.

Ao final do estudo, foi verificado que, uma vez admitido o primeiro incidente em 25 de julho de 2016, as datas de suspensão dos processos afetos variam desde agosto de 2016 a junho de 2018, fato que chama atenção. O histograma representado pela Figura 3 ilustra a frequência de processos suspensos entre a data de admissão do primeiro incidente até a data final da busca, sendo 40 (quarenta) processos ao total.

Figura 3 - Processos suspensos a cada bimestre após a admissão do primeiro incidente

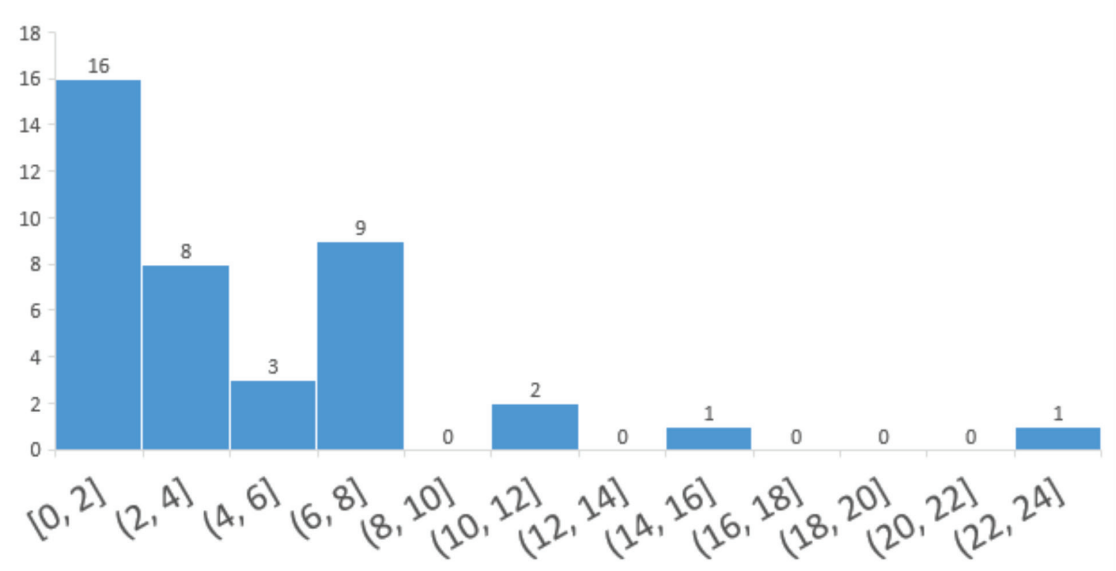

Fonte: desenvolvido pelos autores.

9 O IRDR n. 2016.00.2.020348-4, denominado por IRDR 1; o IRDR n. 2016.00.2.029383-7, denominado por IRDR 2; e o IRDR n. 2016.00.2.034437-7, denominado por IRDR 3.

10 Data de admissão do IRDR 1.

11 Data final da busca.

12 O SIRDR n. 1/DF (2016/0320182-5). 
A correta identificação e consequente divulgação do tema objeto do incidente têm especial relevância, pois, após a sua instauração, será a partir da identificação da causa de pedir de determinado processo que se analisará a veiculação da mesma tese jurídica, o que, se positivo, acarretará em sua suspensão e posterior aplicação da tese consolidada no incidente. O objetivo da técnica é possibilitar a identificação da questão jurídica apreciada no incidente para fins de aplicação ou distinção em relação aos processos eventualmente afetos, sejam pendentes como futuros (MENDES; TEMER, 2015, p. 293).

No caso em análise, com a exceção de 4 (quatro) processos (os processos '17', '22', '31' e '39' - Tabela 2, anexos), todos foram distribuídos antes da admissão do primeiro incidente, inclusive entre os anos de 2014 e 2015, o que não justifica a morosidade de até 2 (dois) anos na suspensão de parte dos processos afetos.

Esses resultados vêm a tornar sem efeito a previsão do art. 980, de que o incidente será julgado no prazo de 1 (um) ano e terá preferência sobre os demais feitos (ressalvados os que envolvam réu preso e os pedidos de habeas corpus).

\subsection{POSSÍVEIS APLICAÇÕES DE ML AO SISTEMA DE PRECEDENTES}

Como exposto no decorrer do estudo, o CPC de 2015, ao estabelecer um sistema de precedentes, visa à entrega da prestação jurisdicional com maior qualidade, como também atender aos objetivos processuais da segurança jurídica, estabilidade, coerência, celeridade e eficiência. Considerando os resultados obtidos com os dois casos analisados, é possível, então, identificar dois campos desse sistema que poderão ser aperfeiçoamento com o uso de sistemas de IA, em especial, por meio da técnica de ML, a partir das seguintes aplicações:

1. Auxílio na observância de decisões anteriores (precedentes já formados): o que se propõe, a partir da técnica de ML, é que o agente inteligente possa auxiliar o julgador a buscar decisões precedentes que se assemelham ao caso em análise ou cujos fatos e fundamentos jurídicos lhe estejam relacionados, evitando-se a não observância ou a decisão presente com base na transcrição pura de ementas que, uma vez reproduzidas em alto grau, incorrem em grandes probabilidades de erro no sentido de fundamentar a decisão presente com a decisão equivocada.

A Figura 4, além de ilustrar o processo de ML nesse caso, aponta algumas tarefas que hoje são desempenhadas pelo julgador e sua equipe e que poderão ser realizadas pela máquina de forma distribuída. Assim, enquanto a cognição humana proporciona o desempenho das tarefas em um processo por vez, a máquina poderá escalonar essa capacidade, resultando no desempenho das tarefas em mais de um processo por vez e com maior velocidade.

Figura 4 - Processo de aprendizado na observância de precedentes 


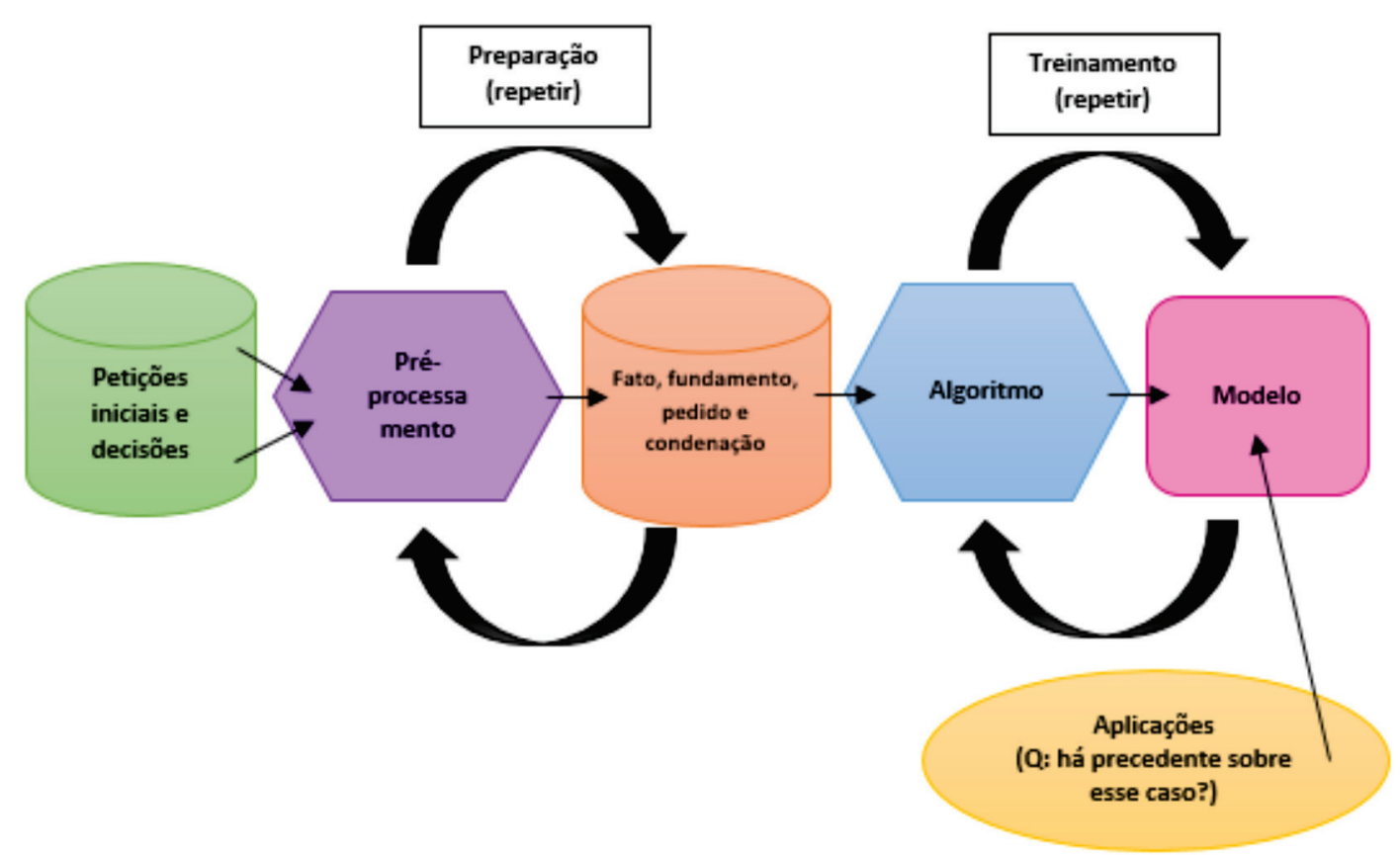

Fonte: adaptado pelos autores com base em Chappell (2015, p. 5).

Assim como nos trabalhos relacionados, a tarefa maior do algoritmo diz respeito à classificação dos textos jurídicos. Nessa aplicação em específico, a sistemática proposta pelo trabalho de El Jelali, Fersini e Messina (2015) se aproxima da lógica acima. Para que o magistrado obtenha a resposta à pergunta "há precedente sobre esse caso?", são necessárias duas frentes na base de dados: a frente das decisões judiciais consideradas precedentes e a frente das petições iniciais.

Na primeira frente, já é possível constatar uma primeira dificuldade: o que é considerada uma decisão precedente? O local de coleta de dados está definido, qual seja, o repositório do STF e do STJ, cujas decisões deverão ser filtradas pelas hipóteses do art. 927 do CPC de 2015. Algumas dessas hipóteses são específicas, como é o caso das decisões consolidadas em súmulas. Outras, porém, são mais amplas, como a orientação de plenário ou órgão especial. Isso significa que a formação da base deverá contar com o trabalho de especialistas no domínio jurídico para dizer se determinada decisão é considerada precedente ou não (o que pode ser denominado por "golden data", isto é, dados que mais se aproximam da realidade).

$\mathrm{Na}$ segunda frente da base não se visualiza maiores dificuldades. As petições iniciais deverão ser coletadas em qualquer local do Poder Judiciário, desde que pertinentes à matéria constitucional e infraconstitucional.

Assim, caberá ao algoritmo associar o texto contido na petição inicial ao texto contido nas decisões consideradas precedentes, recuperando-as ao magistrado e sua equipe. Nesse ambiente de textos, algumas partes são mais relevantes - as variáveis - como os fatos, os fundamentos jurídicos e o pedido (na petição inicial), e também o relatório do acórdão (na decisão considerada precedente). Deve-se ressaltar que a menção de decisões impertinentes no 
conteúdo das petições iniciais é outra variável que poderá prejudicar a acurácia nos resultados.

2. Auxílio ao gerenciamento (aplicação e distinção) de demandas repetitivas (precedentes em formação): $\mathrm{O}$ que se propõe é que o agente inteligente, a partir da técnica de ML, possibilite a correta identificação dos processos abrangidos pela tese jurídica, gerenciando adequadamente as demandas repetitivas.

A Figura 5, além de ilustrar o processo de ML nesse caso, aponta algumas tarefas que hoje são desempenhadas pelo julgador e sua equipe e que poderão ser realizadas pela máquina de forma distribuída no momento de gerenciar demandas repetitivas. De igual forma, as tarefas poderão ser desempenhadas pela máquina em mais de um processo por vez e com maior velocidade.

Figura 5 - Processo de aprendizado no gerenciamento de demandas repetitivas

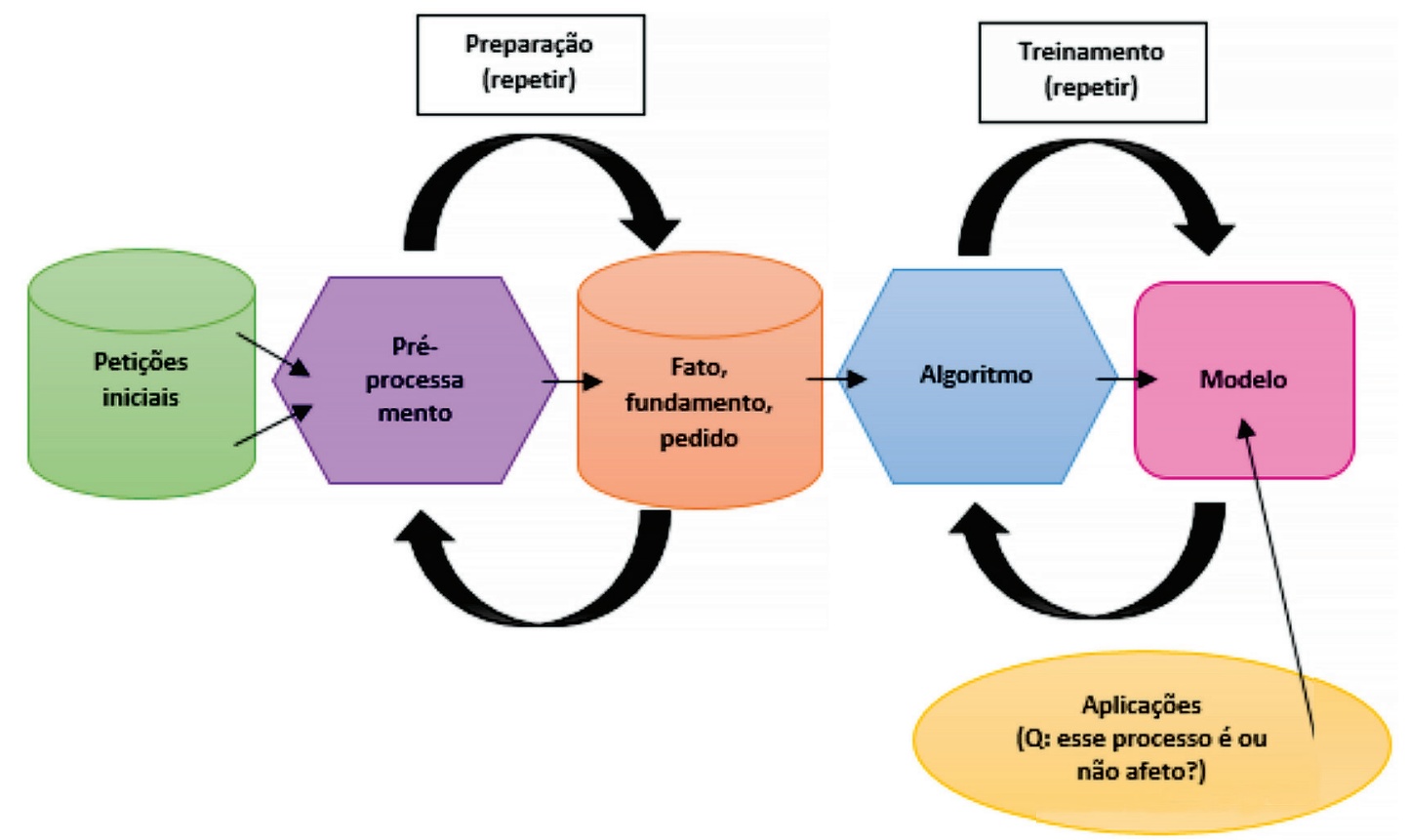

Fonte: adaptado pelos autores com base em Chappell (2015, p. 5).

O agente inteligente, em meio ao ambiente de grande número de demandas repetitivas, poderá auxiliar o julgador a partir da percepção do padrão almejado, efetuando a correta e imediata aplicação e distinção dos processos passíveis de serem submetidos a esse padrão, isto é, à questão jurídica debatida no âmbito do incidente ou, ainda, de recurso especial/extraordinário. Isso reduzirá as probabilidades de processos suspensos equivocadamente, além de agilizar a comunicação aos processos afetos, para que estes sejam tão logo suspensos, evitando trâmites processuais desnecessários.

Da mesma forma que na aplicação anterior, há um trabalho de classificação dos textos jurídicos. Nesse caso, a sistemática proposta no trabalho de Aletras et al. (2016) se aproxima da dinâmica exposta, uma vez que a classificação também é binária, vide a pergunta "esse processo é ou não afeto?". Para que o magistrado obtenha essa resposta, a base de aplicação 
será menor e mais específica: as petições iniciais relativas à tese jurídica fixada.

O local de coleta de dados é definível, qual seja, o Município/Estado em que o fato jurídico responsável pelas demandas ocorreu. Nessa segunda proposta de aplicação, considerando que as situações apresentadas à máquina são semelhantes (em razão de sua especificidade), do ponto de vista da aprendizagem por exemplos, entende-se que a acurácia poderá será maior em relação à primeira proposta de aplicação, pois lá existem matérias jurídicas debatidas diversificadas.

Nesse ambiente de textos, algumas partes são mais relevantes - as variáveis - como os fatos e os fundamentos jurídicos (na petição inicial), e também a tese fixada no acórdão (na decisão que admite o IRDR). Entretanto, outra variável que poderá prejudicar os resultados (e a correta afetação do processo) é a eventual necessidade de se analisar algum documento que acompanha a petição inicial, o que requer treinamento não apenas para dados textuais, mas também para imagens e áudios.

Tendo em conta que o conteúdo dos dados textuais em ambas as aplicações é semelhante - os institutos processuais envolvidos dizem respeito ao sistema geral de precedentes no Brasil -, não se descarta a possibilidade de experimentos visando verificar a portabilidade entre os modelos alcançados, como realizado no trabalho de Glaser, Scepankova e Matthes (2018).

No que se refere à taxa de acurácia (ou assertividade), em ambas as aplicações, tendo em conta os trabalhos relacionados - 79\% (setenta e nove por cento) em Aletras et al. (2016) e 93\% no projeto VICTOR (SILVA, 2018) -, considera-se que a taxa de acurácia acima de $75 \%$ (setenta e cinco) reflete que a máquina já poderá auxiliar o julgador, o advogado, os serventuários da Justiça, entre outros interessados, de maneira veloz e com probabilidades de erro (humano) reduzidas.

Ainda, deve-se observar que a possibilidade de financiamento dessas aplicações potencializa os experimentos, à vista dos custos computacionais (tempo e espaço), especialmente em termos de hardwares para treinamento. Tanto o projeto VICTOR como o sistema e-JRM contaram com apoio financeiro dos órgãos judiciários que se beneficiarão dos resultados (SILVA, 2018; TOLEDO, 2018; EL JELALI; FERSINI; MESSINA, 2015).

Finalmente, desafios gerais dessa inserção na busca da jurisdição inteligente são inevitáveis, como a não estruturação (ou estruturação não uniforme) dos dados nas petições iniciais e nas decisões, e, ainda, a escolha do algoritmo apropriado para cada situação específica.

\section{CONCLUSÃO}

Como visto no levantamento bibliográfico e documental, a classificação da jurisdição no cenário contemporâneo tende a ser superada, uma vez que é natural que os sistemas judiciais, dadas as realidades complexas de cada sociedade e as transformações culturais, almejem maior qualidade à prestação jurisdicional, ainda que, para tanto, seja necessário extrair práticas oriundas de jurisdições estrangeiras, na tentativa de se atingir resultados positivos.

Em que pese à vigência recente do CPC de 2015, os resultados logrados com os estudos 
de casos, partindo da coleta de dados processuais, apontaram para um cenário em que se identificam entraves no cumprimento das disposições processuais (no que se refere à observância dos precedentes e ao gerenciamento de demandas repetitivas), o que gera um problema de ilegitimidade da própria imposição legal, ou seja, de inefetividade da norma.

A IA não pretende substituir o papel do julgador, do advogado ou dos serventuários da Justiça. Ao contrário, as tecnologias a ela inerentes, uma vez aplicadas aos instrumentos da jurisdição, intenta auxiliar esses papéis no sentido de efetivar o que foi imposto pelo CPC de 2015, elevando-se a funcionalidade e a efetividade da norma, bem como a sua legitimidade. A própria celeridade processual é, como dito, o âmago do processo eletrônico, sem a qual o acesso à Justiça sequer se concretizaria, dado o aumento exponencial de demandas em trâmite no Poder Judiciário.

A partir disso, é possível debater a respeito de uma jurisdição inteligente, desapegada de categorizações, na qual a tecnologia, em especial a técnica de ML, seja um instrumento para se alcançar segurança jurídica, previsibilidade, celeridade e coerência das decisões judiciais.

As aplicações que visam a aperfeiçoar a prestação jurisdicional, propostas a partir dos resultados obtidos, tendo em conta o modelo atual brasileiro, são exemplos iniciais de abertura à implementação de ML/IA. Não se descarta que, para a realização dessas tarefas, sejam necessários outros atributos de um agente inteligente, como também não se ignora a existência de outros campos cuja inserção das tecnologias atingirá resultados positivos na prestação jurisdicional.

Sugere-se, portanto, em via de trabalhos futuros, a proposição de modelos e de experimentos aplicados aos campos aqui identificados, ocasião em que o estudo da IA deverá ser aprofundado na correlação com a jurisdição civil contemporânea.

\section{REFERÊNCIAS}

ABRÃO, Carlos Henrique. Processo eletrônico: processo digital. 5. ed. Rio de Janeiro: Atlas, 2017.

ALETRAS, Nikolaos et al. Predicting judicial decisions of the European Court of Human Rights: a natural language processing perspective. PeerJ Computer Science, v. 2, n. 93, p. 1-19, 2016.

ALPAYDIN, Ethem. Introduction to machine learning. 2. ed. Cambridge, MA: MIT Press, 2009.

BRASIL. Lei n. 13.105, de 16 de março de 2015. CPC. Diário Oficial [da] República Federativa do Brasil, Brasília, DF, 16 mar. 2015. Disponível em: http://www.planalto.gov. br/ccivil_03/_ato2015-2018/2015/lei/113105.htm. Acesso em: 22 abr. 2018.

CALAMANDREI, Piero. Studi sul processo civile. Padova: CEDAM, 1957.

CARNELUTTI, Francesco. Teoria geral do direito. Tradução Antônio Carlos Ferreira. São Paulo: LEJUS, 2000. 
CHAPPELL, David. Introducing azure machine learning: a guide for technical professionals. Microsoft Corporation, 2015.

CHIOVENDA, Giuseppe. Instituições de direito processual civil. Tradução Paolo Capitanio. 2. ed. Campinas: Bookseller, 2000.

COLE, Charles D. Stare decisis na cultura jurídica dos Estados Unidos. O sistema de precedente vinculante do common law. Revista dos Tribunais, v. 752, p. 11, jun. 1998.

DAMASKA, Mirjan R. The faces of justice and state authority: a comparative approach to the legal process. New Haven and London: Yale University Press, 1986.

EL JELALI, Soufiane; FERSINI, Elisabetta; MESSINA, Enza. Legal retrieval as support to eMediation: matching disputant's case and court decisions. Artificial Intelligence and Law, v. 23, n. 1, p. 1-22, mar. 2015.

GLASER, Ingo; SCEPANKOVA, Elena; MATTHES, Florian. Classifying semantic types of legal sentences: portability of machine learning models. In: PALMIRANI, M. (ed.). Legal Knowledge and Information Systems. Groningen/Netherlands: IOS Press, 2018. p. 61-70.

MENDES, Aluisio Gonçalves de Castro; TEMER, Sofia. O incidente de resolução de demandas repetitivas do novo Código de Processo Civil. Revista de Processo, v. 243, p. 283. 331, maio. 2015.

MEZZAROBA, Mariana et al. Introdução ao Judiciário Eletrônico. In: ROVER, Aires José (org.). Engenharia e gestão do judiciário brasileiro: estudos sobre e-justiça. Erechim: Deviant, 2016. p. 15-30.

MEZZAROBA, Orides; MONTEIRO, Cláudia Servilha. Manual de metodologia da pesquisa no direito. 3. ed. São Paulo: Saraiva, 2006.

MITCHELL, Tom M. Machine learning. Ithaca, NY: McGraw-Hill, 1997.

OLIVEIRA, Pedro Miranda de. A força das decisões judiciais. Revista de Processo, v. 216, p. 13, fev. 2013.

PONTES DE MIRANDA, Francisco Cavalcanti. Tratado das ações. Atualizado por Vilson Rodrigues Alves. Campinas: Bookseller, 1998. t. I.

RE, Edward D. "Stare decisis”. Revista de Processo, v. 73, p. 47, jan. 1994.

ROVER, Aires José. Informática no Direito: inteligência artificial. Curitiba: Juruá, 2001.

RUSSEL, Stuart; NORVIG, Peter. Inteligência artificial. Tradução PubliCare Consultoria. Rio de Janeiro: Elsevier, 2004.

SCHMITZ, Leonard. Compreendendo os "precedentes” no Brasil: fundamentação de deci- 
sões com base em outras decisões. Revista de Processo, v. 226, p. 349, 2013.

SILVA, Nilton Correia da. Notas iniciais sobre a evolução dos algoritmos do VICTOR: o primeiro projeto de inteligência artificial em supremas cortes do mundo. In: FERNANDES, Ricardo Vieira de Carvalho; CARVALHO, Angelo Gamba Prata de Carvalho (coord.). Tecnologia jurídica $\mathbb{\&}$ direito digital: II Congresso Internacional de Direito, Governo e Tecnologia - 2018. Belo Horizonte: Fórum, 2018. p. 89-94.

TARUFFO, Michele. Observações sobre os modelos processuais de civil law e de common law. Revista de Processo, v. 110, p. 141, abr. 2003.

TOLEDO, Eduardo S. Projetos de inovação tecnológica na Administração Pública. In: FERNANDES, Ricardo Vieira de Carvalho; CARVALHO, Angelo Gamba Prata de (coord.). Tecnologia jurídica $\&$ direito digital: II Congresso Internacional de Direito, Governo e Tecnologia - 2018. Belo Horizonte: Fórum, 2018. p. 83-87.

WAMBIER, Teresa Arruda Alvim. Estabilidade e adaptabilidade como objetivos do direito: civil law e common law. Revista de Processo, São Paulo, n. 172, p. 121-174, jun. 2009.

WINSTON, Patrick Henry. Artificial intelligence. 3. ed. Reading, MA: Addison-Wesley, 1992.

WINSTON, Patrick Henry. The AI business: the commercial uses of artificial intelligence. Cambridge, MA/London, EN: MIT Press, 1984.

APÊNDICE A - Tabela 1 - Reclamações autuadas e julgadas pelo STJ no período de 18/03/2016 a $04 / 07 / 2018$

\begin{tabular}{c|c|c|c|c|c|c}
\cline { 2 - 7 } \multicolumn{2}{c}{} & 'Rcl' & \multicolumn{1}{c}{$\begin{array}{c}\text { Data de } \\
\text { Autuação }\end{array}$} & \multicolumn{1}{c}{$\begin{array}{c}\text { Data de } \\
\text { Julgamento }\end{array}$} & \multicolumn{1}{c}{$\begin{array}{c}\text { Data de } \\
\text { Publicação }\end{array}$} & \multicolumn{2}{c}{$\begin{array}{c}\text { Tipo da } \\
\text { Decisão }\end{array}$} & $\begin{array}{c}\text { Resultado do } \\
\text { Julgamento }\end{array}$ \\
\hline 1 & 30906 & $28 / 3 / 2016$ & $22 / 3 / 2017$ & $28 / 3 / 2017$ & Acórdão & Procedente \\
\hline 2 & 30870 & $28 / 3 / 2016$ & $23 / 11 / 2016$ & $19 / 12 / 2016$ & Acórdão & Procedente \\
\hline 3 & 30972 & $30 / 3 / 2016$ & $13 / 6 / 2018$ & $22 / 6 / 2018$ & Acórdão & Procedente \\
\hline 4 & 31005 & $10 / 4 / 2016$ & $9 / 8 / 2017$ & $15 / 8 / 2017$ & Acórdão & Procedente \\
\hline 5 & 31368 & $14 / 4 / 2016$ & $21 / 6 / 2017$ & $3 / 8 / 2017$ & Acórdão & Improcedente \\
\hline 6 & 31503 & $26 / 4 / 2016$ & $7 / 12 / 2016$ & $15 / 12 / 2016$ & Acórdão & Procedente \\
\hline 7 & 31612 & $9 / 5 / 2016$ & $27 / 9 / 2017$ & $17 / 10 / 2017$ & Acórdão & Improcedente \\
\hline 8 & 31629 & $9 / 5 / 2016$ & $20 / 9 / 2017$ & $28 / 9 / 2017$ & Acórdão & $\begin{array}{c}\text { Parcialmente } \\
\text { Procedente }\end{array}$ \\
\hline 9 & 31636 & $10 / 5 / 2016$ & $27 / 9 / 2017$ & $26 / 10 / 2017$ & Acórdão & Procedente \\
\hline
\end{tabular}




\begin{tabular}{|c|c|c|c|c|c|c|}
\hline 10 & 31631 & $10 / 5 / 2016$ & $10 / 5 / 2017$ & $15 / 5 / 2017$ & Acórdão & Procedente \\
\hline 11 & 31799 & 29/5/2016 & $13 / 12 / 2017$ & $19 / 12 / 2017$ & Acórdão & Improcedente \\
\hline 12 & 31856 & $3 / 6 / 2016$ & $10 / 5 / 2017$ & $15 / 5 / 2017$ & Acórdão & Improcedente \\
\hline 13 & 31899 & $7 / 6 / 2016$ & $24 / 8 / 2016$ & $30 / 8 / 2016$ & Acórdão & Procedente \\
\hline 14 & 31924 & $9 / 6 / 2016$ & $23 / 11 / 2016$ & $29 / 11 / 2016$ & Acórdão & Improcedente \\
\hline 15 & 31930 & $9 / 6 / 2016$ & $24 / 8 / 2016$ & 29/8/2016 & Acórdão & $\begin{array}{l}\text { Parcialmente } \\
\text { Procedente }\end{array}$ \\
\hline 16 & 31991 & $15 / 6 / 2016$ & $17 / 8 / 2016$ & $30 / 8 / 2016$ & Acórdão & Procedente \\
\hline 17 & 32015 & $20 / 6 / 2016$ & $9 / 11 / 2016$ & $16 / 11 / 2016$ & Acórdão & Procedente \\
\hline 18 & 32208 & $19 / 7 / 2016$ & $8 / 2 / 2017$ & $13 / 2 / 2017$ & Acórdão & Procedente \\
\hline 19 & 32273 & $26 / 7 / 2016$ & $10 / 5 / 2017$ & $23 / 6 / 2017$ & Acórdão & Improcedente \\
\hline 20 & 32285 & $28 / 7 / 2016$ & $22 / 3 / 2017$ & $27 / 3 / 2017$ & Acórdão & Procedente \\
\hline 21 & 32391 & $11 / 8 / 2016$ & $13 / 12 / 2017$ & $18 / 12 / 2017$ & Acórdão & Não conhecida \\
\hline 22 & 32394 & $12 / 8 / 2016$ & $27 / 9 / 2017$ & $3 / 10 / 2017$ & Acórdão & Procedente \\
\hline 23 & 32424 & $16 / 8 / 2016$ & $8 / 2 / 2017$ & $17 / 2 / 2017$ & Acórdão & Improcedente \\
\hline 24 & 32426 & $16 / 8 / 2016$ & $8 / 2 / 2017$ & $13 / 2 / 2017$ & Acórdão & Improcedente \\
\hline 25 & 32479 & $23 / 8 / 2016$ & $8 / 3 / 2017$ & $15 / 3 / 2017$ & Acórdão & Procedente \\
\hline 26 & 32491 & $24 / 8 / 2016$ & $23 / 11 / 2016$ & $3 / 2 / 2017$ & Acórdão & Procedente \\
\hline 27 & 32616 & $13 / 9 / 2016$ & $26 / 10 / 2016$ & $8 / 11 / 2016$ & Acórdão & Improcedente \\
\hline 28 & 32697 & $22 / 9 / 2016$ & 08/11/2017 & $20 / 11 / 2017$ & Acórdão & Procedente \\
\hline 29 & 32777 & $5 / 10 / 2016$ & $22 / 2 / 2017$ & $7 / 3 / 2017$ & Acórdão & Procedente \\
\hline 30 & 32825 & $13 / 10 / 2016$ & $10 / 5 / 2017$ & $15 / 5 / 2017$ & Acórdão & Procedente \\
\hline 31 & 32872 & $21 / 10 / 2016$ & $24 / 05 / 2017$ & $30 / 5 / 2017$ & Acórdão & Procedente \\
\hline 32 & 32914 & $28 / 10 / 2016$ & $14 / 12 / 2016$ & $19 / 12 / 2016$ & Acórdão & Improcedente \\
\hline 33 & 32937 & $3 / 11 / 2016$ & $28 / 6 / 2017$ & $1 \% / 8 / 2017$ & Acórdão & Não conhecida \\
\hline 34 & 33057 & $23 / 11 / 2016$ & $24 / 05 / 2017$ & $30 / 5 / 2017$ & Acórdão & Procedente \\
\hline 35 & 33069 & $24 / 11 / 2016$ & $26 / 4 / 2017$ & $5 / 5 / 2017$ & Acórdão & Improcedente \\
\hline 36 & 33102 & $30 / 11 / 2016$ & $26 / 4 / 2017$ & $3 / 5 / 2017$ & Acórdão & Procedente \\
\hline 37 & 33156 & $6 / 12 / 2016$ & $22 / 3 / 2017$ & $24 / 3 / 2017$ & Acórdão & Procedente \\
\hline 38 & 33162 & $7 / 12 / 2016$ & $22 / 2 / 2017$ & $17 / 04 / 2017$ & Acórdão & Não conhecida \\
\hline 39 & 33539 & $12 / 12 / 2016$ & $9 / 8 / 2017$ & $21 / 8 / 2017$ & Acórdão & Procedente \\
\hline 40 & 33327 & $18 / 1 / 2017$ & $24 / 5 / 2017$ & $31 / 5 / 2017$ & Acórdão & Procedente \\
\hline 41 & 33351 & $24 / 1 / 2017$ & $25 / 10 / 2017$ & $30 / 10 / 2017$ & Acórdão & Procedente \\
\hline
\end{tabular}




\begin{tabular}{|c|c|c|c|c|c|c|}
\hline 42 & 33366 & $28 / 01 / 2017$ & $26 / 4 / 2017$ & $2 / 5 / 2017$ & Acórdão & Procedente \\
\hline 43 & 33380 & $31 / 1 / 2017$ & $26 / 4 / 2017$ & $3 / 5 / 2017$ & Acórdão & Procedente \\
\hline 44 & 33715 & $23 / 3 / 2017$ & $11 / 4 / 2018$ & $15 / 5 / 2018$ & Acórdão & Procedente \\
\hline 45 & 33747 & $28 / 3 / 2017$ & $25 / 10 / 2017$ & $30 / 10 / 2017$ & Acórdão & Improcedente \\
\hline 46 & 33746 & $28 / 3 / 2017$ & $23 / 8 / 2017$ & $31 / 8 / 2017$ & Acórdão & Improcedente \\
\hline 47 & 33782 & $3 / 4 / 2017$ & $10 / 5 / 2017$ & $16 / 5 / 2017$ & Acórdão & Improcedente \\
\hline 48 & 33793 & $4 / 4 / 2017$ & $27 / 9 / 2017$ & $3 / 10 / 2017$ & Acórdão & Improcedente \\
\hline 49 & 33794 & $4 / 4 / 2017$ & $9 / 8 / 2017$ & $15 / 8 / 2017$ & Acórdão & Improcedente \\
\hline 50 & 33863 & $16 / 4 / 2017$ & $22 / 11 / 2017$ & $27 / 11 / 2017$ & Acórdão & Procedente \\
\hline 51 & 33862 & $16 / 4 / 2017$ & $9 / 8 / 2017$ & $16 / 8 / 2017$ & Acórdão & Procedente \\
\hline 52 & 33944 & $25 / 4 / 2017$ & $23 / 8 / 2017$ & $31 / 8 / 2017$ & Acórdão & Procedente \\
\hline 53 & 33949 & $26 / 4 / 2017$ & $23 / 8 / 2017$ & $31 / 8 / 2017$ & Acórdão & $\begin{array}{l}\text { Parcialmente } \\
\text { Procedente }\end{array}$ \\
\hline 54 & 34013 & $10 / 5 / 2017$ & $14 / 3 / 2018$ & $27 / 3 / 2018$ & Acórdão & Improcedente \\
\hline 55 & 34014 & $10 / 5 / 2017$ & $28 / 6 / 2017$ & $1 \% / 8 / 2017$ & Acórdão & Não provida \\
\hline 56 & 34030 & $15 / 5 / 2017$ & $14 / 6 / 2017$ & $22 / 6 / 2017$ & Acórdão & Improcedente \\
\hline 57 & 34065 & $22 / 5 / 2017$ & $13 / 6 / 2018$ & 20/6/2018 & Acórdão & Improcedente \\
\hline 58 & 34099 & $26 / 5 / 2017$ & $13 / 9 / 2017$ & $21 / 9 / 2017$ & Acórdão & Improcedente \\
\hline 59 & 34157 & $6 / 6 / 2017$ & $13 / 9 / 2017$ & 20/9/2017 & Acórdão & Procedente \\
\hline 60 & 34161 & $7 / 6 / 2017$ & $25 / 10 / 2017$ & $30 / 10 / 2017$ & Acórdão & Improcedente \\
\hline 61 & 34189 & $9 / 6 / 2017$ & $13 / 9 / 2017$ & $18 / 9 / 2017$ & Acórdão & Improcedente \\
\hline 62 & 34208 & $13 / 6 / 2017$ & $22 / 2 / 2018$ & $1 \% / 3 / 2018$ & Acórdão & Improcedente \\
\hline 63 & 34216 & $14 / 6 / 2017$ & $13 / 9 / 2017$ & $18 / 9 / 2017$ & Acórdão & Improcedente \\
\hline 64 & 34308 & $4 / 7 / 2017$ & $13 / 12 / 2017$ & $15 / 12 / 2017$ & Acórdão & Improcedente \\
\hline 65 & 34559 & $15 / 8 / 2017$ & $11 / 4 / 2018$ & $15 / 5 / 2018$ & Acórdão & Improcedente \\
\hline 66 & 34880 & 26/9/2017 & $11 / 4 / 2018$ & $16 / 4 / 2018$ & Acórdão & Procedente \\
\hline 67 & 34928 & $5 / 10 / 2017$ & $11 / 4 / 2018$ & $20 / 4 / 2018$ & Acórdão & Procedente \\
\hline 68 & 35073 & $6 / 11 / 2017$ & $28 / 2 / 2018$ & $7 / 3 / 2018$ & Acórdão & Procedente \\
\hline 69 & 35076 & $6 / 11 / 2017$ & $22 / 2 / 2018$ & $27 / 2 / 2018$ & Acórdão & Improcedente \\
\hline 70 & 35104 & 8/11/2017 & $13 / 6 / 2018$ & $19 / 6 / 2018$ & Acórdão & Não conhecida \\
\hline 71 & 35262 & $7 / 12 / 2017$ & $14 / 3 / 2018$ & $27 / 3 / 2018$ & Acórdão & Procedente \\
\hline 72 & 35715 & $17 / 1 / 2018$ & $13 / 6 / 2018$ & $18 / 6 / 2018$ & Acórdão & Procedente \\
\hline 73 & 35487 & $19 / 2 / 2018$ & $25 / 4 / 2018$ & $4 / 5 / 2018$ & Acórdão & Improcedente \\
\hline
\end{tabular}




\begin{tabular}{l|l|l|l|l|l|l}
\hline 74 & 35483 & $19 / 2 / 2018$ & $25 / 4 / 2018$ & $2 / 5 / 2018$ & Acórdão & Improcedente \\
\hline 75 & 35762 & $16 / 4 / 2018$ & $13 / 6 / 2018$ & $21 / 6 / 2018$ & Acórdão & Improcedente \\
\hline
\end{tabular}

Fonte: desenvolvido pelos autores.

APÊNDICE B - Tabela 2 - Processos suspensos em razão dos IRDRs em trâmite no TJDFT no período de 25/7/2016 a 4/7/2018

\begin{tabular}{|c|c|c|c|c|c|}
\hline & $\begin{array}{l}\text { Número do } \\
\text { Processo }\end{array}$ & $\begin{array}{c}\text { Data da } \\
\text { Distribuição }\end{array}$ & Vara & Turma & $\begin{array}{l}\text { Data da } \\
\text { Suspensão }\end{array}$ \\
\hline 1 & 2015.01.1.030936-2 & $20 / 3 / 2015$ & $\begin{array}{c}\text { 13a Vara Cível de } \\
\text { Brasília }\end{array}$ & $\begin{array}{c}\text { 5a Turma }^{\text {a }} \\
\text { Cível }\end{array}$ & $2 / 8 / 2016$ \\
\hline 2 & 2015.01.1.144495-0 & $17 / 12 / 2015$ & $\begin{array}{c}\text { 3a Vara Cível de } \\
\text { Brasília }\end{array}$ & $\begin{array}{c}\text { 4a Turma } \\
\text { Cível }\end{array}$ & $2 / 8 / 2016$ \\
\hline 3 & 2014.01.1.008582-9 & $22 / 1 / 2014$ & $\begin{array}{c}\text { 20a Vara Cível de } \\
\text { Brasília }\end{array}$ & $\begin{array}{l}\text { 4a Turma } \\
\text { Cível }\end{array}$ & $2 / 8 / 2016$ \\
\hline 4 & 2014.01.1.158892-6 & $14 / 10 / 2014$ & $\begin{array}{c}\text { 7a Vara Cível de } \\
\text { Brasília }\end{array}$ & $\begin{array}{l}\text { 1a Turma } \\
\text { Cível }\end{array}$ & $3 / 8 / 2016$ \\
\hline 5 & $2015.09 .1 .005330-2$ & $9 / 3 / 2015$ & $\begin{array}{l}\text { 2a Vara Cível de } \\
\text { Samambaia }\end{array}$ & $\begin{array}{l}\text { 1a Turma } \\
\text { Cível }\end{array}$ & $3 / 8 / 2016$ \\
\hline 6 & 2014.11.1.003781-3 & $11 / 7 / 2014$ & $\begin{array}{c}\text { Vara Cível, de } \\
\text { Família e de Órfãos e } \\
\text { Sucessões do Núcleo } \\
\text { Bandeirante }\end{array}$ & $\begin{array}{l}\text { 6a Turma } \\
\text { Cível }\end{array}$ & $16 / 8 / 2016$ \\
\hline 7 & 2015.01.1.026040-8 & $10 / 3 / 2015$ & $\begin{array}{c}\text { 12a Vara Cível de } \\
\text { Brasília } \\
\end{array}$ & $\begin{array}{c}\text { 3a Turma } \\
\text { Cível }\end{array}$ & $22 / 8 / 2016$ \\
\hline 8 & 2014.07.1.023873-7 & $25 / 7 / 2014$ & $\begin{array}{c}\text { 5a }^{\text {Vara Cível de }} \\
\text { Taguatinga }\end{array}$ & - & $24 / 8 / 2016$ \\
\hline 9 & 2015.01.1.124890-7 & $29 / 10 / 2015$ & $\begin{array}{c}\text { 5a Vara Cível de } \\
\text { Brasília }\end{array}$ & $\begin{array}{l}\text { 1a Turma } \\
\text { Cível }\end{array}$ & $30 / 8 / 2016$ \\
\hline 10 & 2014.09.1.023431-0 & $10 / 10 / 2014$ & $\begin{array}{c}\text { 1a Vara Cível de } \\
\text { Samambaia }\end{array}$ & $\begin{array}{l}\text { 6a Turma } \\
\text { Cível }\end{array}$ & $30 / 8 / 2016$ \\
\hline 11 & $2015.01 .1 .068817-0$ & $16 / 6 / 2015$ & $\begin{array}{c}\text { 3a Vara Cível de } \\
\text { Brasília }\end{array}$ & $\begin{array}{c}\text { 1a Turma } \\
\text { Cível }\end{array}$ & $31 / 8 / 2016$ \\
\hline 12 & $2015.01 .1 .065020-2$ & $3 / 6 / 2015$ & $\begin{array}{c}\text { 2a Vara Cível de } \\
\text { Brasília }\end{array}$ & $\begin{array}{l}\text { 4a Turma } \\
\text { Cível }\end{array}$ & $8 / 9 / 2016$ \\
\hline
\end{tabular}




\begin{tabular}{|c|c|c|c|c|c|}
\hline 13 & 2014.01.1.200582-4 & $19 / 12 / 2014$ & $\begin{array}{c}\text { 6a Vara Cível de } \\
\text { Brasília }\end{array}$ & $\begin{array}{c}\text { 6}^{\mathrm{a}} \text { Turma } \\
\text { Cível }\end{array}$ & 20/9/2016 \\
\hline 14 & $2012.01 .1 .165022-0$ & $22 / 10 / 2012$ & $\begin{array}{c}\text { 13a Vara Cível de } \\
\text { Brasília }\end{array}$ & $\begin{array}{c}\text { 5a Turma } \\
\text { Cível }\end{array}$ & $26 / 9 / 2016$ \\
\hline 15 & 2014.01.1.111647-7 & $23 / 7 / 2014$ & $\begin{array}{c}\text { 8a Vara Cível de } \\
\text { Brasília }\end{array}$ & $\begin{array}{l}\text { 4a Turma } \\
\text { Cível }\end{array}$ & 29/9/2016 \\
\hline 16 & 2016.09.1.013052-3 & 28/6/2016 & $\begin{array}{l}\text { 2a Vara Cível de } \\
\text { Samambaia }\end{array}$ & - & $7 / 10 / 2016$ \\
\hline 17 & 2016.01.1.085754-8 & $17 / 8 / 2016$ & $\begin{array}{c}\text { 18 } \text { Vara Cível de } \\
\text { Brasília }\end{array}$ & - & $24 / 10 / 2016$ \\
\hline 18 & 2015.01.1.046000-4 & $24 / 4 / 2015$ & $\begin{array}{c}\text { 25a Vara Cível de } \\
\text { Brasília }\end{array}$ & - & $14 / 11 / 2016$ \\
\hline 19 & 2013.01.1.102732-0 & $19 / 7 / 2013$ & $\begin{array}{c}\text { 19a Vara Cível de } \\
\text { Brasília }\end{array}$ & $\begin{array}{l}\text { 6a Turma } \\
\text { Cível }\end{array}$ & $29 / 11 / 2016$ \\
\hline 20 & 2014.01.1.200616-9 & $19 / 12 / 2014$ & $\begin{array}{c}\text { 25a Vara Cível de } \\
\text { Brasília }\end{array}$ & $\begin{array}{c}\text { 6a Turma } \\
\text { Cível }\end{array}$ & $1 \% / 12 / 2016$ \\
\hline 21 & 2015.01.1.050701-7 & $5 / 5 / 2015$ & $\begin{array}{c}\text { 11 }{ }^{\text {a Vara Cível de }} \\
\text { Brasília }\end{array}$ & $\begin{array}{c}\text { 5a Turma } \\
\text { Cível }\end{array}$ & $5 / 12 / 2016$ \\
\hline 22 & 2016.01.1.086352-0 & $18 / 8 / 2016$ & $\begin{array}{c}\text { 19a Vara Cível de } \\
\text { Brasília }\end{array}$ & - & $7 / 12 / 2016$ \\
\hline 23 & 2015.01.1.054582-7 & $13 / 5 / 2015$ & $\begin{array}{c}\text { 15a Vara Cível de } \\
\text { Brasília }\end{array}$ & $\begin{array}{c}\text { 5a Turma } \\
\text { Cível }\end{array}$ & $14 / 12 / 2016$ \\
\hline 24 & 2014.09.1.015439-6 & $11 / 7 / 2014$ & $\begin{array}{c}\text { 1a Vara Cível de } \\
\text { Samambaia }\end{array}$ & $\begin{array}{c}\text { 4a Turma } \\
\text { Cível }\end{array}$ & $15 / 12 / 2016$ \\
\hline 25 & 2016.01.1.079231-3 & $29 / 7 / 2016$ & $\begin{array}{c}\text { 19a Vara Cível de } \\
\text { Brasília }\end{array}$ & - & $13 / 1 / 2017$ \\
\hline 26 & $2015.01 .1 .120115-4$ & $20 / 10 / 2015$ & $\begin{array}{c}\text { 13a Vara Cível de } \\
\text { Brasília }\end{array}$ & $\begin{array}{c}\text { 5a Turma } \\
\text { Cível }\end{array}$ & $23 / 1 / 2017$ \\
\hline 27 & 2015.01.1.019137-5 & $24 / 2 / 2015$ & $\begin{array}{c}\text { 16a Vara Cível de } \\
\text { Brasília }\end{array}$ & $\begin{array}{c}\text { 4a Turma } \\
\text { Cível }\end{array}$ & $25 / 1 / 2017$ \\
\hline 28 & 2015.01.1.021535-3 & $27 / 2 / 2015$ & $\begin{array}{c}\text { 2a Vara Cível de } \\
\text { Brasília }\end{array}$ & $\begin{array}{l}\text { 1a Turma } \\
\text { Cível }\end{array}$ & $20 / 2 / 2017$ \\
\hline 29 & 2014.01.1.200815-8 & $22 / 12 / 2014$ & $\begin{array}{c}\text { 1a Vara Cível de } \\
\text { Brasília }\end{array}$ & - & $22 / 02 / 2017$ \\
\hline 30 & 2016.01.1.062500-2 & $7 / 6 / 2016$ & $\begin{array}{c}\text { 11 }{ }^{\text {a Vara Cível de }} \\
\text { Brasília }\end{array}$ & $\begin{array}{l}\text { 1a Turma } \\
\text { Cível }\end{array}$ & $22 / 2 / 2017$ \\
\hline
\end{tabular}




\begin{tabular}{|c|c|c|c|c|c|}
\hline 31 & 2016.01.1.094626-2 & $8 / 9 / 2016$ & $\begin{array}{c}\text { 25a Vara Cível de } \\
\text { Brasília }\end{array}$ & - & $23 / 2 / 2017$ \\
\hline 32 & 2014.01.1.075487-4 & $19 / 5 / 2014$ & $\begin{array}{c}\text { 18a Vara Cível de } \\
\text { Brasília }\end{array}$ & $\begin{array}{c}\text { 5a Turma } \\
\text { Cível }\end{array}$ & $15 / 3 / 2017$ \\
\hline 33 & 2016.01.1.001140-6 & $11 / 1 / 2016$ & $\begin{array}{c}\text { 2a Vara Cível de } \\
\text { Brasília }\end{array}$ & - & $30 / 3 / 2017$ \\
\hline 34 & 2015.01.1.081758-7 & $21 / 7 / 2015$ & $\begin{array}{c}\text { 22a Vara Cível de } \\
\text { Brasília }\end{array}$ & $\begin{array}{l}\text { 1a Turma } \\
\text { Cível }\end{array}$ & $31 / 3 / 2017$ \\
\hline 35 & 2016.09.1.006127-3 & $16 / 3 / 2016$ & $\begin{array}{l}\text { 20 Juizado Especial } \\
\text { Cível e Criminal de } \\
\text { Samambaia }\end{array}$ & $\begin{array}{c}\text { 3a Turma } \\
\text { Recursal } \\
\text { dos Juizados } \\
\text { Especiais } \\
\text { Cíveis }\end{array}$ & $6 / 4 / 2017$ \\
\hline 36 & $2014.01 .1 .200082-7$ & $19 / 12 / 2014$ & $\begin{array}{c}\text { 11'a Vara Cível de } \\
\text { Brasília }\end{array}$ & $\begin{array}{l}\text { 1a Turma } \\
\text { Cível }\end{array}$ & $18 / 4 / 2017$ \\
\hline 37 & 2015.09.1.018521-3 & $25 / 8 / 2015$ & $\begin{array}{c}\text { 2a Vara Cível de } \\
\text { Samambaia }\end{array}$ & $\begin{array}{c}\text { 4a Turma } \\
\text { Cível }\end{array}$ & $24 / 7 / 2017$ \\
\hline 38 & 2016.01.1.052976-2 & $9 / 5 / 2016$ & $\begin{array}{c}\text { 6a Vara Cível de } \\
\text { Brasília }\end{array}$ & - & $26 / 7 / 2017$ \\
\hline 39 & 2017.01.1.006372-8 & $2 / 2 / 2017$ & $\begin{array}{c}\text { 1a Vara Cível de } \\
\text { Brasília }\end{array}$ & - & $23 / 11 / 2017$ \\
\hline 40 & 2015.09.1.000081-2 & $7 / 1 / 2015$ & $\begin{array}{l}\text { 2a Vara Cível de } \\
\text { Samambaia }\end{array}$ & $\begin{array}{c}\text { 6a Turma } \\
\text { Cível }\end{array}$ & $25 / 6 / 2018$ \\
\hline
\end{tabular}

Fonte: desenvolvido pelos autores.

\section{NOTA}

Artigo "OBSERVÂNCIA DE PRECEDENTES E GESTÃO DE DEMANDAS REPETITIVAS POR MEIO DO APRENDIZADO DE MÁQUINA”.

Responsabilidade da autoria:

Coleta de dados, pesquisa bibliográfica e redação: Isabela Cristina Sabo.

Organização metodológica, revisão e orientação científica: Aires José Rover. 